\title{
Dual anti-platelet therapy following percutaneous coronary intervention in a population of patients with thrombocytopenia at baseline: a meta- analysis
}

Manyun Long, Ziliang Ye, Jing Zheng, Wuxian Chen and Lang Li*

\begin{abstract}
Background: In this meta-analysis, we aimed to systematically compare the post percutaneous coronary interventional (PCI) adverse bleeding events, stent thrombosis, stroke and other cardiovascular outcomes in a population of patients with and without thrombocytopenia at baseline who were followed up on dual antiplatelet therapy (DAPT).

Methods: Relevant English language articles which were published before June 2019 were retrieved from MEDLINE, http://www.ClinicalTrials.com, EMBASE, Cochrane central, and Google scholar briefly using specific terms such as percutaneous coronary intervention or dual antiplatelet therapy, and thrombocytopenia. All the participants were followed up on DAPT following discharge. Specific endpoints including bleeding events, stent thrombosis, stroke and other adverse cardiovascular events were assessed. The latest version of the RevMan software was used for the statistical assessment. Odd ratios (OR) with 95\% confidence intervals (Cl) based on a fixed or a random statistical model were used to represent the data graphically.

Results: A total number of 118,945 participants (from 8 studies) were included with 37,753 suffering from thrombocytopenia at baseline. Our results showed post procedural bleeding (OR: 1.89, 95\% Cl: 1.16-3.07; $P=$ 0.01 ), access site bleeding (OR: 1.66, 95\% Cl: 1.15-2.39; $P=0.006)$, intra-cranial bleeding (OR: 1.78 , 95\% Cl: $1.30-$ 2.43; $P=0.0003)$, gastro-intestinal bleeding (OR: 1.44, 95\% Cl: 1.14-1.82; $P=0.002)$ and any major bleeding (OR: 1.67, $95 \% \mathrm{Cl}: 1.42-1.97 ; P=0.00001)$ to be significantly higher in thrombocytopenic patients treated with DAPT after $\mathrm{PCl}$. Total stroke (OR: 1.45, 95\% Cl: 1.18-1.78; $P=0.0004)$ specifically hemorrhagic stroke (OR: 1.67, 95\% Cl: 1.30-2.14; $P=0.0001$ ) was also significantly higher in these patients with thrombocytopenia at baseline. Allcause mortality and major adverse cardiac events were also significantly higher. However, overall total stent thrombosis (OR: 1.18, 95\% Cl: 0.90-1.55; $P=0.24$ ) including definite and probable stent thrombosis were not significantly different compared to the control group.

(Continued on next page)
\end{abstract}

\footnotetext{
*Correspondence: drrlilang@126.com

Department of Cardiology, the First Affiliated Hospital of Guangxi Medical University, Guangxi Cardiovascular institute, Nanning, Guangxi 530021, P.R. China
}

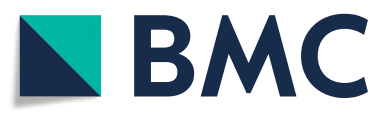

( The Author(s). 2020 Open Access This article is licensed under a Creative Commons Attribution 4.0 International License, which permits use, sharing, adaptation, distribution and reproduction in any medium or format, as long as you give appropriate credit to the original author(s) and the source, provide a link to the Creative Commons licence, and indicate if changes were made. The images or other third party material in this article are included in the article's Creative Commons licence, unless indicated otherwise in a credit line to the material. If material is not included in the article's Creative Commons licence and your intended use is not permitted by statutory regulation or exceeds the permitted use, you will need to obtain permission directly from the copyright holder. To view a copy of this licence, visit http://creativecommons.org/licenses/by/4.0/ The Creative Commons Public Domain Dedication waiver (http://creativecommons.org/publicdomain/zero/1.0/) applies to the data made available in this article, unless otherwise stated in a credit line to the data. 
(Continued from previous page)

Conclusions: According to the results of this analysis, DAPT might have to be cautiously be used following $\mathrm{PCl}$ in a population of patients with thrombocytopenia at baseline due to the significantly higher bleeding rate including gastro-intestinal, intra-cranial bleeding and hemorrhagic stroke. Hence, special care might have to be taken when considering anti-platelet agents following $\mathrm{PCl}$ in these high risk patients. However, considering the present limitations of this analysis, this hypothesis will have to be confirmed in future trials.

Keywords: Percutaneous coronary intervention, Cardiovascular diseases, Thrombocytopenia, Low platelets, Bleeding, Stent thrombosis, Hemorrhagic stroke, Dual anti-platelet therapy

\section{Background}

Management of cardiovascular diseases (CVD) or acute coronary syndrome (ACS) in patients with thrombocytopenia has not often been an easy task for physicians due to the associated bleeding risks [1]. Anticoagulants and antiplatelet agents during and after percutaneous coronary intervention (PCI) respectively, are vital in patients with CVD [2, 3]. However, in this particular category of patients with a low platelet count at baseline, the use of dual antiplatelet therapy (DAPT) with aspirin and a P2Y12 inhibitor might be a risk [4]. The management of such patients with antiplatelet agents is challenging especially for physicians considering the fact that no current guidelines or recommendations are available to clearly and precisely guide physicians about how to manage patients with thrombocytopenia following PCI $[5,6]$.

This high risk group of patients has not yet well been investigated. Several reasons including a lack of evidence for the treatment and management of patients with thrombocytopenia following coronary angioplasty, as well as the statement in an editorial implying that nothing can be done to reduce bleeding risk in this category of patients following PCI [7], and the request for future randomized trials to evaluate the positive and negative effects of different antiplatelet agents or regimens on this category of patients, are the proofs for this ignorance by the research community till date.

In this meta-analysis, we aimed to systematically compare the post PCI adverse bleeding events, stent thrombosis, stroke and other cardiovascular outcomes in a population of patients with and without thrombocytopenia at baseline who were followed up on DAPT.

\section{Methods}

\section{Sources of data}

Articles which were published before June 2019 were retrieved from the following electronic search databases: MEDLINE, http://www.ClinicalTrials.com, EMBASE, Cochrane central, and Google scholar.

Furthermore, reference lists of publications which were relevant to coronary angioplasty in patients with thrombocytopenia at baseline were filtered for other suitable articles.

\section{Search strategies}

Specific words or phrases were used to search for publications matching the scope of this current article:

Percutaneous coronary intervention AND thrombocytopenia OR low platelet counts; Dual anti-platelet therapy OR DAPT AND thrombocytopenia OR low platelet counts; Acute coronary syndrome OR ACS AND thrombocytopenia OR low platelet counts; Coronary angioplasty OR PCI AND thrombocytopenia OR low platelet counts.

Our search was restricted only to papers which were published in English language.

\section{Selection criteria (Inclusion and exclusion criteria)}

We included studies based on the following criteria:

- They were studies (randomized trials or observational cohorts including prospective and retrospective studies) comparing PCI in patients with and without thrombocytopenia;

- They were not systematic reviews, meta-analyses, literature reviews, or letters of correspondence;

- Adverse bleeding events, stent thrombosis and/or adverse cardiovascular outcomes were reported among the endpoints;

- They involved patients who were treated by DAPT following PCI;

- They were published in English language;

- They involved patients with thrombocytopenia at baseline. It should be noted that studies involving thrombocytopenia which occurred after PCI were excluded from this analysis.

We excluded studies based on the following criteria:

- They were duplicated studies which were obtained from different search databases;

- They were literature reviews, meta-analyses, systematic reviews or case studies;

- They did not include participants with thrombocytopenia at baseline;

- They were published in another language apart from English; 
- They did not report relevant adverse clinical outcomes.

\section{Definitions and endpoints to be assessed}

In this analysis, thrombocytopenia was defined as a platelet count $<150,000$ cells $/ \mu$ l.

This analysis is based on the assessment of bleeding events, stent thrombosis, stroke and other adverse cardiovascular outcomes in patients with thrombocytopenia at baseline who underwent PCI and who were followed up on DAPT post procedure.

The endpoints which were reported in the original studies have been listed in Table 1.

The endpoints which were considered in this metaanalysis included:

(A) Endpoints assessing bleeding events:

(a) Total bleeding events including any type of bleeding;

(b) Post-procedural bleeding which was defined as bleeding complications immediately after the procedure; (c) Access site bleeding which was defined as bleeding occurring at the site which was accessible for intervention (radial or femoral);

(d) Any minor bleeding (consisting of any type of minor bleeding);

(e) Any major bleeding (consisting of any type of major bleeding);

(f) Bleeding defined according to the academic research consortium (BARC) [16];

BARC type 1: was defined as minimal bleeding that does not require hospital assistance or treatment.

BARC type 2: was defined as any overt bleeding, that does not fit the criteria for type 3,4 and 5, but does meet one of the following criteria: requiring medical or non-surgical intervention by a medical healthcare professional, or leading to hospitalization or increased level of care.

BARC type 3: was defined as overt bleeding with a hemoglobin drop of $3-5 \mathrm{~g} / \mathrm{dl}$, and resulting in blood transfusion.

BARC type 4: was defined as coronary artery bypass grafting related bleeding.

Table 1 Reported outcomes to be assessed

\begin{tabular}{|c|c|c|c|}
\hline Studies & Outcomes which were reported after PCI in the original studies respectively & $\begin{array}{l}\text { Follow-up time } \\
\text { period after PCl }\end{array}$ & Types of CAD \\
\hline $\begin{array}{l}\text { Ayoub } \\
2018[8]\end{array}$ & $\begin{array}{l}\text { Post-procedural hemorrhage, RBC transfusion, platelet transfusion, vascular } \\
\text { complications, acute ischemic CVA, acute hemorrhagic CVA, cardiac } \\
\text { tamponade, mortality }\end{array}$ & In-hospital & $\begin{array}{l}\text { General population with CAD }+ \\
\text { chronic thrombocytopenia undergoing } \\
\mathrm{PCl}\end{array}$ \\
\hline $\begin{array}{l}\text { Ito } 2018 \\
\text { [9] }\end{array}$ & $\begin{array}{l}\text { Myocardial infarction, GUSTO moderate bleeding, GUSTO severe bleeding, all- } \\
\text { cause death, cardiac death, ischemic stroke, all stroke, hemorrhagic stroke, } \\
\text { definite stent thrombosis, definite/probable stent thrombosis, any coronary } \\
\text { revascularization, intracranial bleeding, gastrointestinal bleeding, bleeding re- } \\
\text { lated to surgery, bleeding related to catheterization procedure }\end{array}$ & 3 years & $\begin{array}{l}\text { General population with } \mathrm{CAD}+ \\
\text { thrombocytopenia undergoing } \mathrm{PCl}\end{array}$ \\
\hline $\begin{array}{l}\text { Kiviniemi } \\
2013[10]\end{array}$ & $\begin{array}{l}\text { All-cause mortality, MACCE, stroke, peripheral arterial embolism, myocardial } \\
\text { infarction, revascularization, stent thrombosis, venous thromboembolism, } \\
\text { total bleeding events, minor BARC } 2 \text { bleeding, major BARC bleeding ( } 3 a, 3 b \text {, } \\
3 c, 5)\end{array}$ & 1 year & $\begin{array}{l}\text { CAD and atrial fibrillation }+ \\
\text { thrombocytopenia undergoing } \mathrm{PCl}\end{array}$ \\
\hline $\begin{array}{l}\text { Liu } 2018 \\
{[11]}\end{array}$ & $\begin{array}{l}\text { All-cause mortality, cardiac death, myocardial infarction, revascularization, } \\
\text { bleeding, major bleeding, ischemic stroke, MACE, definite stent thrombosis, } \\
\text { definite and probable stent thrombosis, early, late and very late stent } \\
\text { thrombosis }\end{array}$ & 30 months & $\begin{array}{l}\text { General population with CAD + } \\
\text { thrombocytopenia undergoing } \\
\text { elective PCl }\end{array}$ \\
\hline $\begin{array}{l}\text { Overgaard } \\
2008[12]\end{array}$ & $\begin{array}{l}\text { Mortality, MACE, myocardial infarction, major bleeding, gastro-intestinal bleed, } \\
\text { intracranial hemorrhage, other bleedings, access site complications, } \\
\text { transfusion }\end{array}$ & In-hospital & $\begin{array}{l}\text { General population with } \mathrm{CAD}+ \\
\text { thrombocytopenia undergoing } \mathrm{PCl}\end{array}$ \\
\hline $\begin{array}{l}\text { Raphael } \\
2016 \text { [13] }\end{array}$ & $\begin{array}{l}\text { Femoral bleeding, intra-cerebral bleeding, hematoma, gastro-intestinal bleed- } \\
\text { ing, retroperitoneal bleeding, any bleeding, death, myocardial infarction, ac- } \\
\text { cess site bleeding, BARC } 2 \text { minor bleeding, BARC }(3 a, 3 b, 4) \text { major bleeding }\end{array}$ & In-hospital & $\begin{array}{l}\text { General population with } \mathrm{CAD}+ \\
\text { thrombocytopenia undergoing } \mathrm{PCl}\end{array}$ \\
\hline $\begin{array}{l}\text { Shiraishi } \\
2019[14]\end{array}$ & Mortality, transfusion, access site bleeding & In-hospital & $\begin{array}{l}\text { General population with CAD + } \\
\text { thrombocytopenia undergoing } \\
\text { elective PCI }\end{array}$ \\
\hline $\begin{array}{l}\text { Yadav } \\
2016[15]\end{array}$ & $\begin{array}{l}\text { Death, cardiac death, myocardial infarction, revascularization, definite/ } \\
\text { probable stent thrombosis, MACE }\end{array}$ & 1 year & $\begin{array}{l}\text { ACS (STEMI and NSTEMI) + } \\
\text { thrombocytopenia undergoing PCI }\end{array}$ \\
\hline
\end{tabular}

Abbreviations: $P C I$ percutaneous coronary intervention, $C A D$ coronary artery disease, $A C S$ acute coronary syndrome, $C V A$ cerebrovascular attack, $R B C$ red blood cells, MACCE major adverse cardiac and cerebrovascular events, MACE major adverse cardiac events, BARC bleeding defined according to the academic research consortium 
BARC type 5: was defined as fatal bleeding.

BARC type 1 and 2 were classified as BARC minor bleeding.

BARC type 3-5 were classified as BARC major bleeding.

(g) Intra-cranial bleeding;

(h) Gastro-intestinal bleeding.

(B) Endpoints assessing stent thrombosis:
(a). Overall stent thrombosis;
(b). Definite stent thrombosis;
(c). Definite/probable stent thrombosis defined by the academic research consortium [17].

(C) Endpoints assessing stroke:

(a) Total stroke including ischemic and hemorrhagic stroke;

(b) Ischemic stroke;

(c) Hemorrhagic stroke.

(D) Endpoints assessing adverse cardiovascular outcomes:

(a) All-cause mortality;

(b) Cardiac death;

(c) Revascularization (including target vessel revascularization and/or target lesion revascularization);

(d) Myocardial infarction (MI);

(e) Major adverse cardiac events (MACEs): defined as the composite endpoint including mortality, MI, and revascularization. Since, one study reported major adverse cerebrovascular and cardiovascular events (MACCEs) consisting of all the components of MACEs with the addition of stroke, we have included this outcome along with MACEs.

The original studies had a follow-up time period ranging from an in-hospital follow-up to a time period of 3 years. The respective follow-up time periods have also been listed in Table 1.

\section{Data extraction and quality assessment}

Tables in this paper consisted of vital data which were extracted from the original studies by the authors. Those data included the outcomes (bleeding events, stent thrombosis, stroke and other cardiovascular outcomes) reported, the follow-up time periods (in hospital and longer duration time period), DAPT which were used (drugs involved), the platelet count at baseline, the baseline characteristics of the participants including comorbidities and cardiac risk factors, the total number of participants with versus without thrombocytopenia and so on.

Disagreement which occurred during the data extraction process was resolved among the authors by consensus or by close discussion with the corresponding author. An online platform was set up for the authors to discuss any issue related to the data extraction process. Any disagreement was further discussed by the corresponding author, who was the last one to reach a final decision.

The Newcastle Ottawa Scale (NOS) [18] was used to assess the methodological quality of the observational cohorts whereas the criteria recommended by the Cochrane Collaboration [19] were used to assess the methodological quality of the randomized controlled trials. Grades from A to $\mathrm{C}$ were allotted denoting low, moderate and high risks of bias respectively.

\section{Statistical analysis}

This analysis was carried out with the latest version of the RevMan software (RevMan 5.3). Odds ratios (OR) with $95 \%$ confidence intervals $(\mathrm{CI})$ were used to represent the data graphically.

Heterogeneity assessment was carried out with the Q statistic test and a subgroup analysis with $(P \leq 0.05)$ was considered significant statistically. The $\mathrm{I}^{2}$ statistic test was also used to assess heterogeneity whereby an increase in its value represented an increasing heterogeneity.

Concerning the statistical model which was used: a fixed effect model was used if the heterogeneity value $\mathrm{I}^{2}$ was less than $50 \%$. Or else, a random effect model was used.

In addition to this analysis, sensitivity analysis was also carried out based on an exclusion method.

Publication bias was visually observed by a careful assessment of the funnel plots.

\section{Ethical approval}

No experiment involving animals or humans were carried out by any of the authors. Therefore, an ethical or board review approval was not required for this metaanalysis.

\section{Results}

Outcome of the search process and the selection of studies

Taking into consideration the PRISMA guideline [20], 742 publications were searched through electronic databases. The titles and abstracts were carefully assessed by the authors. Articles which were irrelevant were directly eliminated (654).

Eighty eight (88) full text articles were then assessed based on the eligibility criteria for selection. 
Another set of elimination was carried out based on the following reasons:

- They were literature reviews (3);

- They were case studies (17);

- They were based on thrombocytopenia after PCI and did not involve participants with thrombocytopenia at baseline (26);

- They were letters of correspondence (4);

- They were duplicated studies from several different search databases (30).

Finally, we were remaining with 8 studies [8-15] that satisfied all the criteria for inclusion and exclusion represented by Fig. 1.

\section{Main features of the studies}

Seven studies were observational cohorts whereas one study involved data from a randomized trial. A total number of 118,945 participants were included in this meta-analysis. Thirty seven thousand seven hundred and fifty three $(37,753)$ participants suffered from thrombocytopenia at baseline whereas 81,192 participants were non-thrombocytopenic participants who underwent PCI. The detailed list has been given in Table 2.

The definition of thrombocytopenia reported in each study has also been given in Table 2 .

After an assessment of the studies, a grade B was allotted (moderate risk of bias) to each of the original study.

\section{Baseline features of the participants}

The baseline characteristics of the participants with and without thrombocytopenia have been listed in Table 3 . The mean age (57.9-74.0 years), the mean percentage of participants who were males, who suffered from diabetes mellitus, hypertension, dyslipidemia and who had a history of smoking have been listed in Table 3.

In addition, the anticoagulants or antiplatelet drugs which were used during this invasive procedure and which were prescribed at discharge following PCI were listed in Table 4.

\section{Main clinical endpoints which were assessed}

Our results showed access site bleeding (OR: 1.66, 95\% CI: $1.15-2.39 ; P=0.006)$, any major bleeding (OR: 1.67 , 95\% CI: $1.42-1.97 ; P=0.00001)$, intra-cranial bleeding (OR: $1.78,95 \%$ CI: $1.30-2.43 ; P=0.0003$ ) and gastro-

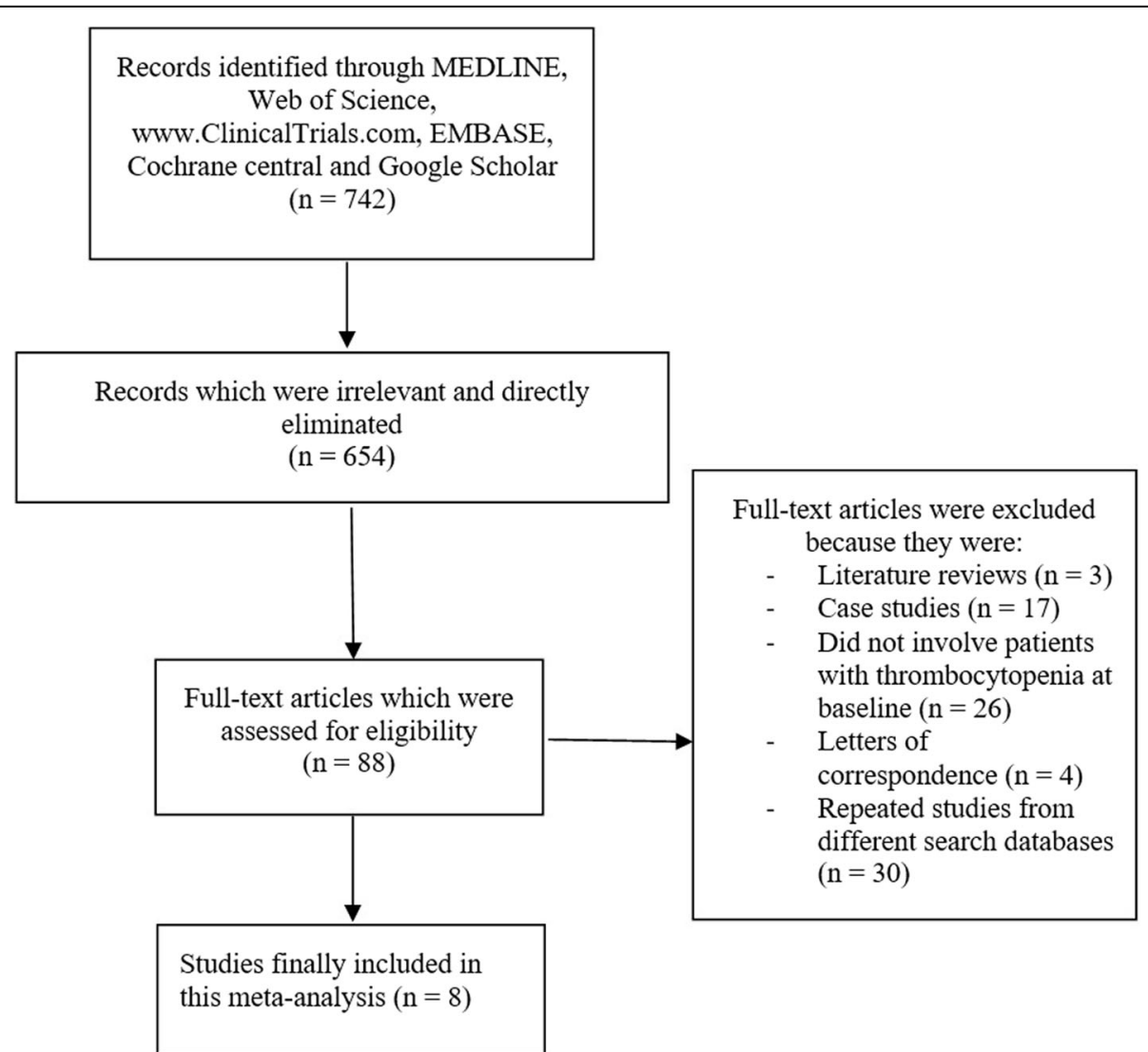

Fig. 1 Flow diagram showing the selection of studies to be included in this meta-analysis 
Table 2 Main features of the studies

\begin{tabular}{|c|c|c|c|c|c|}
\hline Studies & $\begin{array}{l}\text { Type of } \\
\text { study }\end{array}$ & $\begin{array}{l}\text { Methodological } \\
\text { quality grading }\end{array}$ & $\begin{array}{l}\text { No of patients with } \\
\text { thrombocytopenia at baseline (n) }\end{array}$ & $\begin{array}{l}\text { No of patients in the } \\
\text { control group (n) }\end{array}$ & $\begin{array}{l}\text { Average PLT count in the } \\
\text { study group }\end{array}$ \\
\hline Ayoub 2018 [8] & OS & B & 32,565 & 32,565 & $<150,000 \mathrm{cells} / \mu \mathrm{l}$ \\
\hline Ito 2018 [9] & OS & B & 2298 & 16,763 & $100-150,000$ cells $/ \mu l$ \\
\hline Kiviniemi 2013 [10] & OS & B & 99 & 762 & $80-150,000$ cells/ $\mu \mathrm{l}$ \\
\hline Liu 2018 [11] & OS & B & 1263 & 8634 & 50-150,000 cells/ $/ \mu \mathrm{l}$ \\
\hline Overgaard 2008 [12] & OS & B & 639 & 10,182 & $<150,000 \mathrm{cells} / \mu \mathrm{l}$ \\
\hline Raphael 2016 [13] & OS & B & 146 & 1281 & $\leq 100,000 \mathrm{cells} / \mu \mathrm{l}$ \\
\hline Shiraishi 2019 [14] & OS & B & 226 & 1009 & 50,000-149,000 cells/ $/ \mathrm{L}$ \\
\hline Yadav 2016 [15] & RCT & B & 607 & 9996 & 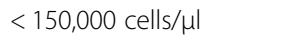 \\
\hline $\begin{array}{l}\text { Total number of } \\
\text { participants (n) }\end{array}$ & & & 37,753 & 81,192 & \\
\hline
\end{tabular}

Abbreviations: PLT platelet, OS observational study, RCT randomized controlled trials

intestinal bleeding (OR: 1.44, 95\% CI: 1.14-1.82; $P=$ 0.002 ) to be significantly higher in this category of patients following PCI as shown in Fig. 2. Any minor bleeding (OR: 1.03, 95\% CI: 0.81-1.30; $P=0.81$ ), BARC minor bleeding (OR: 1.35, 95\% CI: 0.82-2.24; $P=0.24$ ) and BARC major bleeding (OR: 1.44, 95\% CI: 0.86-2.41; $P=$ 0.16) were not significantly different as shown in Fig. 2.

However, when total bleeding event was assessed, it was significantly higher (OR: $3.12,95 \% \mathrm{CI}: 1.28-7.60 ; P=0.01$ ) in the population of patients with thrombocytopenia at baseline as shown in Fig. 3. Total in hospital bleeding (OR: $1.97,95 \%$ CI: $1.41-2.74 ; P=0.0001$ ) was also significantly higher (Fig. 4). Post-procedural bleeding (OR: 1.89, 95\% CI: $1.16-3.07 ; P=0.01)$ was also significantly higher in these patients with thrombocytopenia following coronary stenting as shown in Fig. 3.

Our results showed overall total stent thrombosis (OR: 1.18, 95\% CI: $0.90-1.55 ; P=0.24)$, definite stent thrombosis (OR: $0.94,95 \% \mathrm{CI}: 0.61-1.44 ; P=0.77$ ) and definite/probable stent thrombosis (OR: 1.18, 95\% CI: 0.89$1.55 ; P=0.25)$ not to be significantly different in patients with thrombocytopenia compared to the control group as shown in Fig. 5.

When stroke was assessed, following PCI, total stroke (OR: 1.45 , 95\% CI: $1.18-1.78 ; P=0.0004$ ) was significantly higher in these patients with thrombocytopenia as shown in Fig. 6. Our results showed hemorrhagic stroke (OR: $1.67,95 \% \mathrm{CI}: 1.30-2.14 ; P=0.0001$ ) to be significantly higher in these patients with thrombocytopenia as shown in Fig. 7. Ischemic stroke (OR: 1.34, 95\% CI: 0.93-1.94; $P=0.11$ ) was similarly manifested (Fig. 6).

All-cause mortality (OR: 1.84, 95\% CI: 1.49-2.27; $P=$ 0.00001) and MACEs (OR: 1.32, 95\% CI: 1.04-1.67; $P=$ 0.02 ) were significantly higher in the population of patients with thrombocytopenia as shown in Fig. 8. In hospital mortality (OR: 2.30, 95\% CI: 2.13-2.48; $P=$ 0.00001 ) and in hospital MACEs (OR: 1.73, 95\% CI: $1.20-2.50 ; \quad P=0.004)$ were also significantly higher (Fig. 9). Cardiac death (OR: 1.71, 95\% CI: 1.46-2.00; $P=$ $0.00001)$ was also significantly higher. However, revascularization (OR: 1.05 , 95\% CI: $0.86-1.28 ; P=0.63$ ) and $\mathrm{MI}$ (OR: 1.05 , 95\% CI: $0.89-1.23 ; P=0.59)$ were similar in

Table 3 Baseline characteristics

\begin{tabular}{|c|c|c|c|c|c|c|}
\hline \multirow[t]{2}{*}{ Studies } & Age & Males & T2DM & $\mathrm{HTN}$ & Smoking & DYS \\
\hline & TC/NTC & TC/NTC & TC/NTC & TC/NTC & $\mathrm{TC} / \mathrm{NTC}$ & TC/NTC \\
\hline Ayoub 2018 [8] & $68.8 / 69.3$ & $73.1 / 73.9$ & $45.9 / 46.9$ & $77.1 / 77.9$ & - & - \\
\hline Ito 2018 [9] & $71.8 / 68.0$ & $79.5 / 72.9$ & 44.4/39.6 & $81.5 / 81.8$ & $21.2 / 28.6$ & $39.7 / 42.3$ \\
\hline Kiviniemi 2013 [10] & $74.0 / 73.0$ & $85.0 / 68.0$ & $31.0 / 37.0$ & $76.0 / 85.0$ & $6.00 / 11.0$ & $69.0 / 66.0$ \\
\hline Liu 2018 [11] & $60.9 / 57.9$ & $13.5 / 24.5$ & $35.2 / 29.3$ & $60.9 / 64.8$ & $59.3 / 56.2$ & $65.5 / 67.5$ \\
\hline Overgaard 2008 [12] & $67.0 / 63.0$ & $84.5 / 71.5$ & $32.2 / 26.9$ & $61.7 / 61.3$ & $46.0 / 38.0$ & - \\
\hline Raphael 2016 [13] & $70.6 / 67.4$ & $82.0 / 71.0$ & $44.0 / 30.0$ & $85.0 / 80.0$ & - & $84.0 / 85.0$ \\
\hline Shiraishi 2019 [14] & $74.0 / 72.0$ & $74.8 / 73.4$ & 53./43.8 & $77.4 / 75.9$ & $11.9 / 16.2$ & $60.6 / 66.5$ \\
\hline Yadav 2016 [15] & $65.7 / 61.9$ & $87.3 / 73.8$ & $32.0 / 23.5$ & $67.7 / 61.1$ & $26.9 / 36.0$ & $57.9 / 51.5$ \\
\hline
\end{tabular}

Abbreviations: T2DM type 2 diabetes mellitus, HTN hypertension, DYS dyslipidemia, TC thrombocytopenia group, NTC non-thrombocytopenia group 
Table 4 Intra-procedural and post angioplasty anticoagulants and anti-platelets used

\begin{tabular}{|c|c|c|c|c|}
\hline Studies & Intra-procedural anti-platelets/anti-coagulants & $\begin{array}{l}\text { Post procedural/discharge anti- } \\
\text { platelets (majority) }\end{array}$ & Duration of DAPT use & $\begin{array}{l}\text { Access site } \\
\text { for } \mathrm{PCl}\end{array}$ \\
\hline $\begin{array}{l}\text { Ayoub } \\
2018[8]\end{array}$ & Not mentioned & Not mentioned & Not mentioned & $\begin{array}{l}\text { Not } \\
\text { mentioned }\end{array}$ \\
\hline $\begin{array}{l}\text { Ito } 2018 \\
{[9]}\end{array}$ & Unfractionated heparin & $\begin{array}{l}\text { Aspirin, clopidogrel or } \\
\text { ticlopidine (DAPT) }\end{array}$ & $\geq 3$ months & $\begin{array}{l}\text { Not } \\
\text { mentioned }\end{array}$ \\
\hline $\begin{array}{l}\text { Kiviniemi } \\
2013[10]\end{array}$ & $\begin{array}{l}\text { LMWH (enoxaparin sodium and dalteparin), } \\
\text { unfractionated heparin, bivalirudin, and glycoprotein Ilb/ } \\
\text { Illa inhibitors }\end{array}$ & $\begin{array}{l}\text { Aspirin, clopidogrel and } \\
\text { warfarin Or Aspirin and } \\
\text { clopidogrel (DAPT) }\end{array}$ & $1-3$ months & $\begin{array}{l}\text { Femoral } \\
\text { access }\end{array}$ \\
\hline $\begin{array}{l}\text { Liu } 2018 \\
{[11]}\end{array}$ & Aspirin, clopidogrel, LMWH, glycoprotein Ilb/Illa inhibitors & Aspirin and clopidogrel (DAPT) & $\begin{array}{l}\text { short term use without } \\
\text { mentioning the exact time } \\
\text { duration }\end{array}$ & $\begin{array}{l}\text { Not } \\
\text { mentioned }\end{array}$ \\
\hline $\begin{array}{l}\text { Overgaard } \\
2008[12]\end{array}$ & Not mentioned & Not mentioned & Not mentioned & $\begin{array}{l}\text { Femoral } \\
\text { access }\end{array}$ \\
\hline $\begin{array}{l}\text { Raphael } \\
2016 \text { [13] }\end{array}$ & Aspirin, clopidogrel, heparin & Aspirin and clopidogrel (DAPT) & Not mentioned & $\begin{array}{l}\text { Femoral > } \\
\text { radial } \\
\text { access }\end{array}$ \\
\hline $\begin{array}{l}\text { Shiraishi } \\
2019[14]\end{array}$ & Aspirin, thienopyridine & $\begin{array}{l}\text { Aspirin, clopidogrel, ticlopidine } \\
\text { or prasugrel (DAPT) }\end{array}$ & Not mentioned & $\begin{array}{l}\text { Radial > } \\
\text { femoral } \\
\text { access }\end{array}$ \\
\hline $\begin{array}{l}\text { Yadav } \\
2016[15]\end{array}$ & $\begin{array}{l}\text { Heparin, bivalirudin, and glycoprotein IIb/Illa inhibitors, } \\
\text { aspirin and clopidogrel }\end{array}$ & $\begin{array}{l}\text { Aspirin, clopidogrel, ticlopidine } \\
\text { or prasugrel (DAPT) }\end{array}$ & Not mentioned & $\begin{array}{l}\text { Not } \\
\text { mentioned }\end{array}$ \\
\hline
\end{tabular}

Abbreviations: $L M W H$ low molecular weight heparin, DAPT dual antiplatelet therapy, $P C I$ percutaneous coronary intervention

both the experimental and the control groups as shown in Figs. 8 and 10.

Moreover, in order for the final results not to be influenced by any particular study, a sensitivity analysis was carried out. During this sensitivity analysis, consistent results were obtained throughout. Also, the visual assessment of publication bias was shown in Figs. 11 and 12.

\section{Discussion}

Thrombocytopenia is a rare disorder that affects a minority of patients all around the globe. Due to a low platelet count, these patients are at higher risk for bleeding complications [21]. The use of anticoagulants during and antiplatelet agents after PCI in thrombocytopenic patients with ACS is still controversial and is a dilemma among clinical physicians. Even though platelets have a major contribution in the pathogenesis and occurrence of ACS [22], low platelet counts in thrombocytopenia does not reduce this problem. In contrast, platelets are often larger and hyperactive despite being low in number in these patients with thrombocytopenia.

As described in the result section, several types of bleeding including post-procedural bleeding, access site bleeding, intra-cranial bleeding, gastro-intestinal bleeding and any major bleeding were significantly higher in this population of patients with thrombocytopenia following the use of DAPT after PCI. The overall bleeding risk was high. Hemorrhagic stroke was also higher in this category of patients. However, our analysis showed stent thrombosis to be similar in patients with and without thrombocytopenia who were followed up on DAPT after PCI.

When the other cardiovascular outcomes including all-cause mortality, cardiac death and MACEs were assessed, a significantly higher risk was observed following PCI in these patients with thrombocytopenia at baseline. It should be noted that this high mortality rate might have partly resulted from the significantly higher risks of overall and major bleeding as well as hemorrhagic stroke. In addition, significant bleeding might have resulted in severe MI resulting in a significantly higher level of cardiac death in this category of patients.

The effect of DAPT was further demonstrated in a case study [23] of a 77 year old patient with a history of thrombocytopenia at baseline undergoing PCI with the implantation of drug eluting stents. He was followed up on DAPT with aspirin and ticagrelor. However, during the third day of hospitalization, several episodes of epistaxis were noted, due to which, DAPT was stopped, and the patient was discharged on clopidogrel monotherapy. After 1 year, the patient was reported to be well, without any bleeding event, even with a platelet count of $31-60 \times 10^{9} / \mathrm{L}$.

In a letter of correspondence [24] based on the medical and interventional management of patients with se-

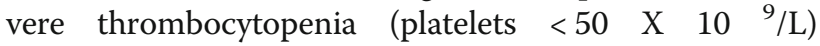
undergoing PCI, the authors stated that PCI is not recommended in patients with severe thrombocytopenia due to the high risk of bleeding events because of the use of peri-procedural anticoagulants and post- 


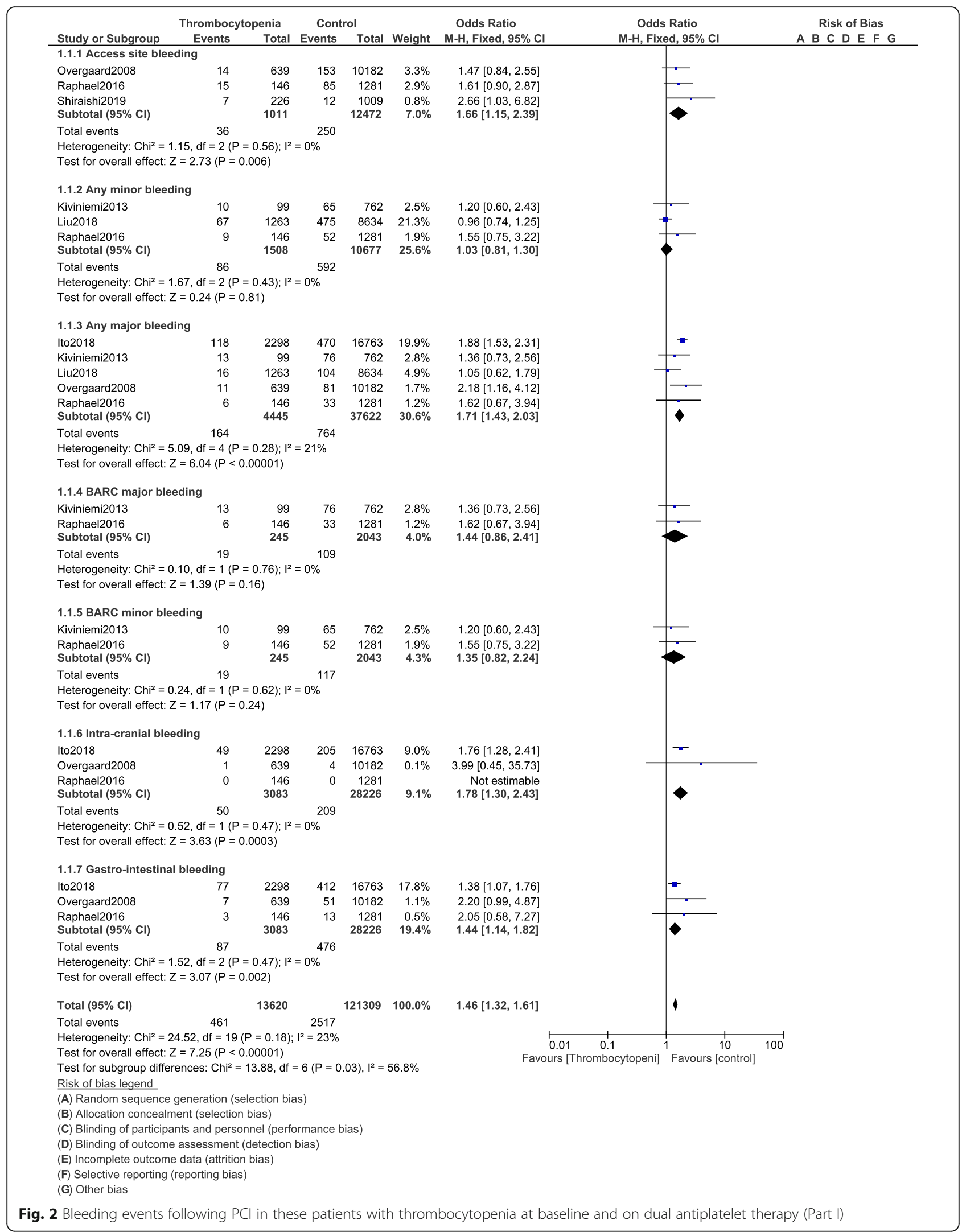




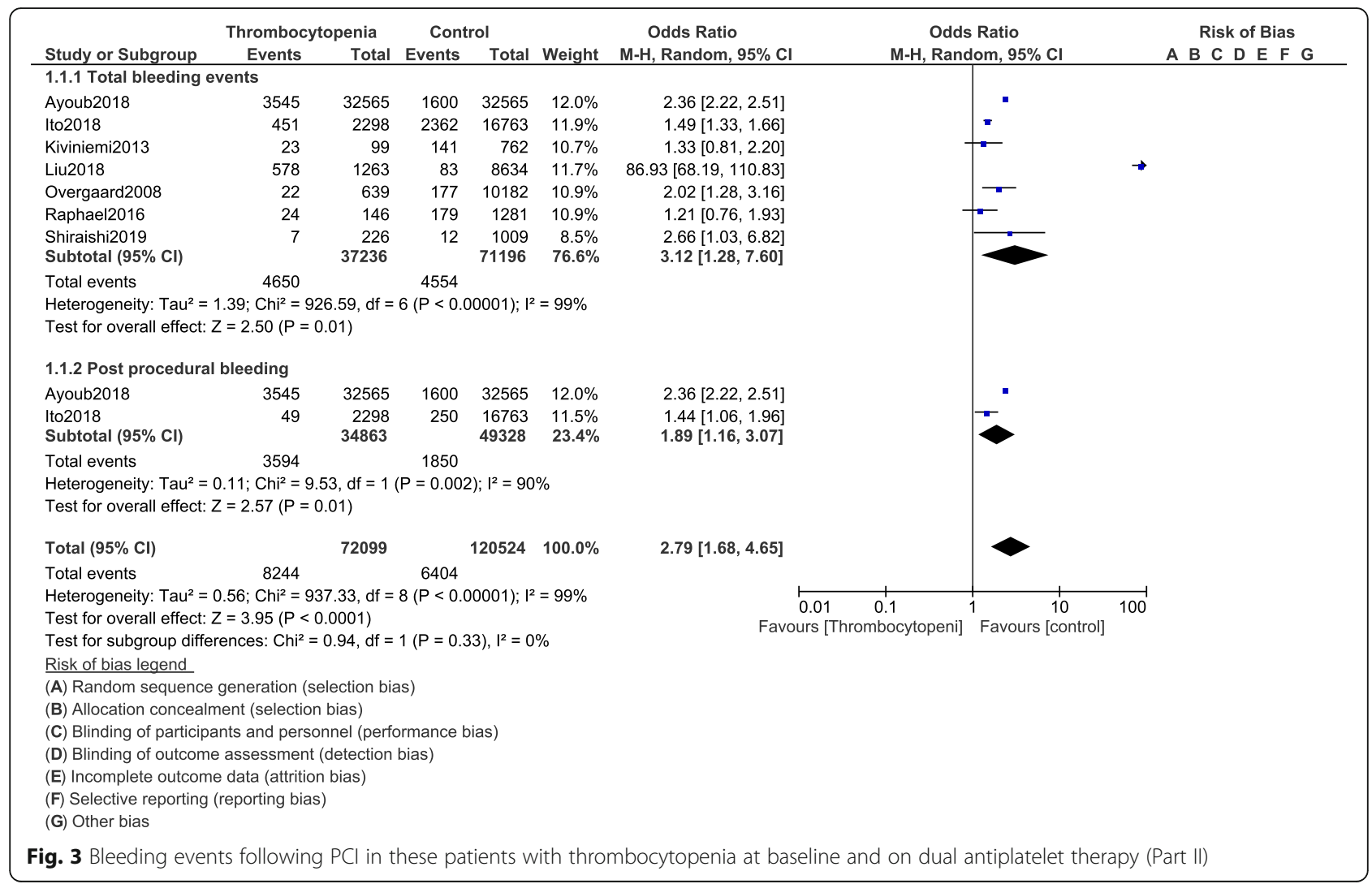

procedural DAPT, hence, data were collected from 35 participants from January 2006 to December 2010 with severe thrombocytopenia at baseline undergoing coronary angioplasty to show the clinical complications and management in these patients. Radial access was considered in these patients to minimize the risk of bleeding events. Among the 35 participants, drug eluting stents were used in only 5 patients while in the remaining, bare metal stents were implanted. Unfractionated heparin was used in most of the patients during the procedure. After the procedure, clopidogrel mono-therapy was initiated in $20 \%$ of the 35 participants. However, after 7 months, the antiplatelet mono-therapy was discontinued in one patient due to increased bleeding complications.

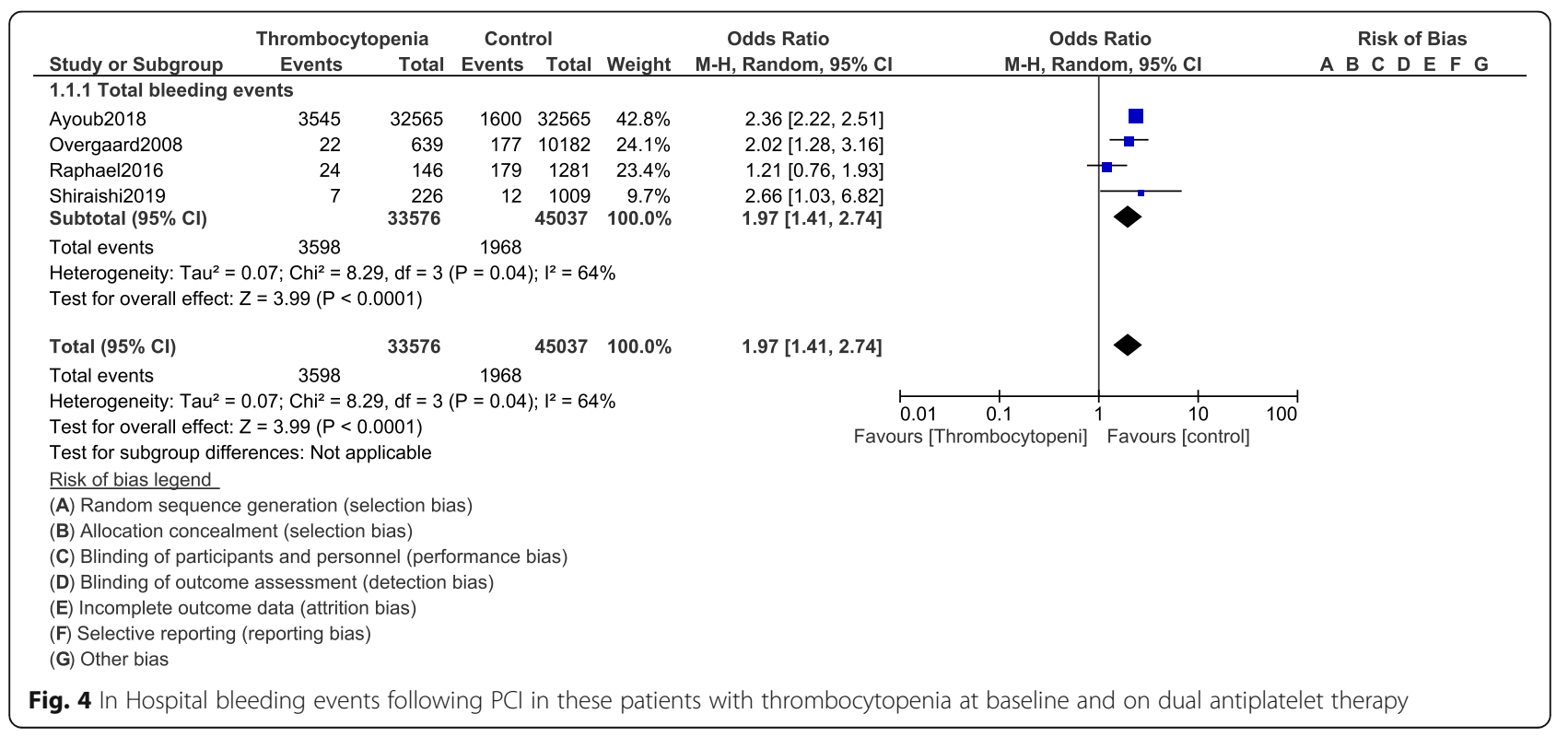




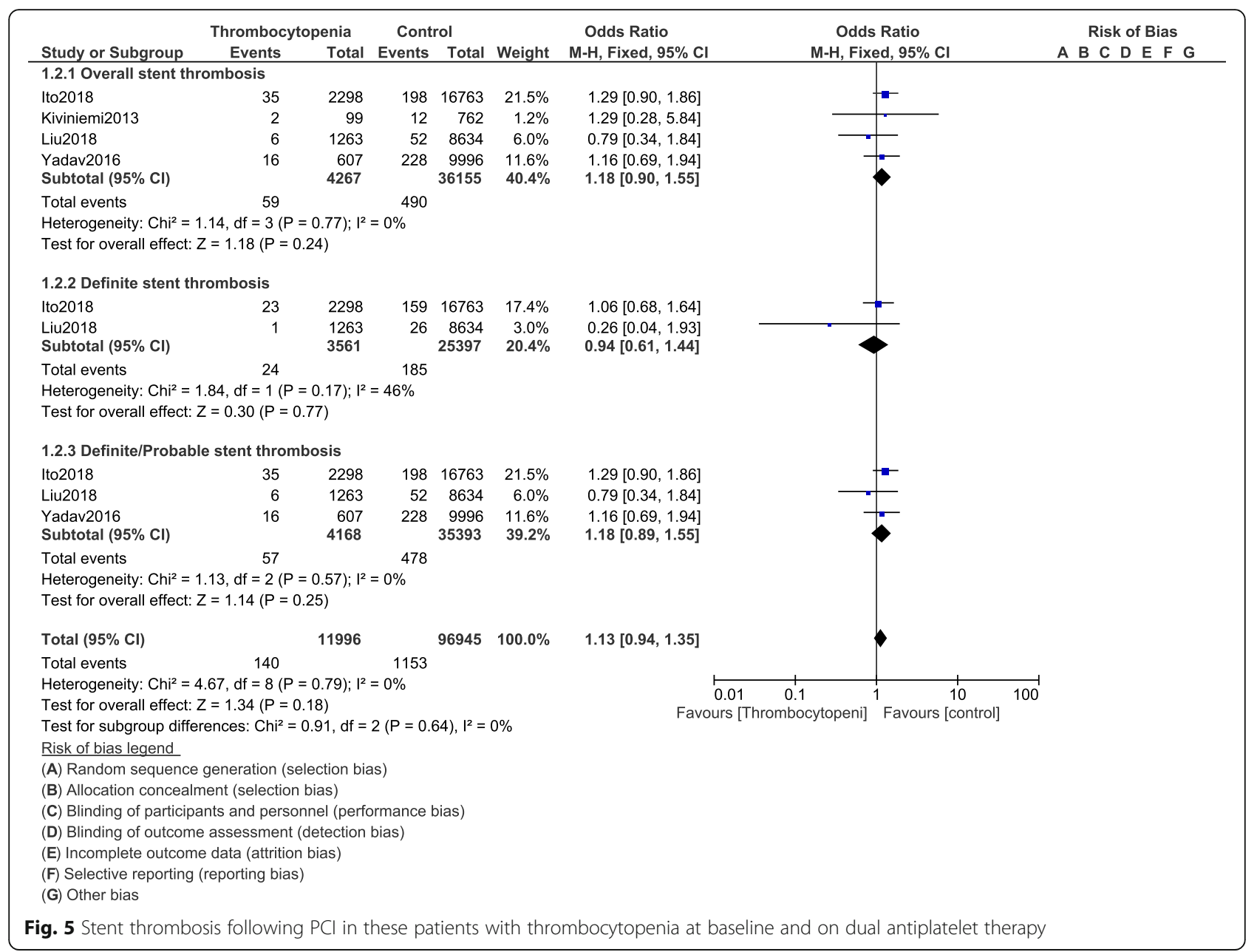

DAPT for 6 months was recommended in another $20 \%$ of the 35 participants, whereby only 5 participants completed the full course. MI was reported in 1 patient who was implanted with bare metal stents and taking aspirin mono-therapy due to stent thrombosis after 3 months of treatment. The authors stated that approximately $50 \%$ of the 35 patients with severe thrombocytopenia experienced bleeding complications. However, bleeding events were superficial, and involved gastro-intestinal and genitourinary bleeds. Among the 7 patients who were on DAPT, 3 patients suffered serious bleeding events, and among the 7 patients who were on clopidogrel monotherapy, 1 patient experienced severe bleeding. The remaining participants were only on aspirin monotherapy and only 2 participants reported severe bleeding complications. It should be noted that antiplatelet regimens were discontinued at the time of bleeding. Nevertheless, in this current analysis, where DAPT was used by the majority of the participants, higher bleeding events were observed and it should be noted that this current analysis also involved far more number of participants (over 10, 000 times more that the above mentioned study). While in the previous study, hemorrhagic bleed was not observed, our current analysis showed significantly higher risk of hemorrhagic stroke among those participants on DAPT after PCI.

Thrombocytopenia co-existing in patients with diseases such as liver cirrhosis, leukemia or patients who are on chemotherapy might be associated with higher risks for severe bleeding events following the use of DAPT. For example, following PCI in a patient with acute myeloid leukemia receiving chemotherapy [25], DAPT was prescribed but the duration was adapted based on the patient's tolerability and circumstance. A personalized treatment strategy should be thought to maintain a balance between the effect and risk for bleeding [26]. Similarly, in cirrhotic patients with coronary artery disease, DAPT while reducing the risk of recurrent myocardial infarction, it was associated with a higher gastrointestinal bleeding [27] which might later result in discontinuation or modification of this antiplatelet regimen.

Optimal DAPT use in patients with ACS has always been a controversial issue. The PRECISE-DAPT and the 


\begin{tabular}{|c|c|c|c|c|c|c|c|c|c|}
\hline \multirow{3}{*}{ Study or Subgroup } & \multicolumn{2}{|c|}{ Thrombocytopenia } & \multicolumn{2}{|c|}{ Control } & \multicolumn{2}{|r|}{ Odds Ratio } & \multirow{2}{*}{\multicolumn{2}{|c|}{$\begin{array}{l}\text { Odds Ratio } \\
\text { M-H, Random, } 95 \% \mathrm{Cl}\end{array}$}} & Risk of Bias \\
\hline & Events & Total & Events & Total & Weight & $\mathrm{M}-\mathrm{H}$, Random, $95 \% \mathrm{Cl}$ & & & $A B C D E F G$ \\
\hline & \multicolumn{9}{|c|}{ 1.4.1 Total stroke } \\
\hline Ayoub2018 & 753 & 32565 & 480 & 32565 & $30.6 \%$ & $1.58[1.41,1.78]$ & & - & \\
\hline Ito2018 & 107 & 2298 & 617 & 16763 & $21.4 \%$ & $1.28[1.04,1.58]$ & & - & \\
\hline Kiviniemi2013 & 0 & 99 & 0 & 762 & & Not estimable & & & \\
\hline Liu2018 & 0 & 1263 & 0 & 8634 & & Not estimable & & & \\
\hline Subtotal $(95 \% \mathrm{Cl})$ & & 36225 & & 58724 & $52.1 \%$ & $1.45[1.18,1.78]$ & & $\bullet$ & \\
\hline Total events & 860 & & 1097 & & & & & & \\
\hline \multicolumn{10}{|c|}{ Heterogeneity: $\mathrm{Tau}^{2}=0.02 ; \mathrm{Chi}^{2}=3.05, \mathrm{df}=1(\mathrm{P}=0.08) ; \mathrm{I}^{2}=67 \%$} \\
\hline \multicolumn{10}{|c|}{ Test for overall effect: $Z=3.52(P=0.0004)$} \\
\hline \multicolumn{10}{|l|}{ 1.4.2 Ischemic stroke } \\
\hline Ayoub2018 & 664 & 32565 & 420 & 32565 & $29.9 \%$ & $1.59[1.41,1.80]$ & & - & \\
\hline Ito2018 & 72 & 2298 & 481 & 16763 & $18.1 \%$ & $1.09[0.85,1.41]$ & & + & \\
\hline Liu2018 & 0 & 1263 & 0 & 8634 & & Not estimable & & & \\
\hline Subtotal $(95 \% \mathrm{Cl})$ & & 36126 & & 57962 & $47.9 \%$ & $1.34[0.93,1.94]$ & & $\rightarrow$ & \\
\hline Total events & 736 & & 901 & & & & & & \\
\hline \multicolumn{10}{|c|}{$\begin{array}{l}\text { Heterogeneity: } \mathrm{Tau}^{2}=0.06 ; \mathrm{Ch}^{2}=6.89, \mathrm{df}=1(P=0.009) ; I^{2}=85 \% \\
\text { Test for overall effect: } Z=1.58(P=0.11)\end{array}$} \\
\hline Total $(95 \% \mathrm{Cl})$ & & 72351 & & 116686 & $100.0 \%$ & $1.42[1.22,1.64]$ & & $\bullet$ & \\
\hline \multicolumn{10}{|c|}{$\begin{array}{lll}\text { Total events } & 1596 & 1998\end{array}$} \\
\hline \multicolumn{10}{|c|}{ Heterogeneity: $\mathrm{Tau}^{2}=0.02 ; \mathrm{Chi}^{2}=9.98, \mathrm{df}=3(P=0.02) ; 1^{2}=70 \%$} \\
\hline \multirow{2}{*}{\multicolumn{10}{|c|}{$\begin{array}{l}\text { Test for subgroup differences: } \mathrm{Chi}^{2}=0.13, \mathrm{df}=1(\mathrm{P}=0.72), \mathrm{I}^{2}=0 \% \\
\text { Risk of bias legend }\end{array}$}} \\
\hline & & & & & & & & & \\
\hline \multicolumn{10}{|c|}{ (A) Random sequence generation (selection bias) } \\
\hline \multicolumn{10}{|c|}{ (B) Allocation concealment (selection bias) } \\
\hline \multicolumn{10}{|c|}{ (C) Blinding of participants and personnel (performance bias) } \\
\hline \multirow{2}{*}{\multicolumn{10}{|c|}{ (D) Blinding of outcome assessment (detection bias) }} \\
\hline & & & & & & & & & \\
\hline \\
\hline \multicolumn{10}{|c|}{$\begin{array}{l}\text { (F) Selective reporting (reporting bias) } \\
\text { (G) Other bias }\end{array}$} \\
\hline Fig. 6 Stroke follow & $\mathrm{ng} P C l$ in th & se patie & ents witl & h throm & nbocyto & nia at baseline and & on dual antiplatelet & therapy (Part I) & \\
\hline
\end{tabular}

PARIS risk scores were recently developed to facilitate the choice for individualized optimal DAPT use with aspirin and ticagrelor or prasugrel following PCI [28]. Four thousand four hundred twenty-four participants were followed up for 14 months upon discharge after revascularization by PCI. Major bleeding risk was stratified and data supported the use of the PRECISE-DAPT for such patients whereas the PARIS risk score was more appropriate for prediction in patients with respect to ischemic events.

Furthermore, in an individual data pairwise and network meta-analysis of six randomized trials and 11, 473 patients [29], the authors demonstrated that 3 months DAPT use appeared safe in stable coronary artery patients. The authors also concluded that prolonged DAPT use might increase bleeding risk regardless of clinical

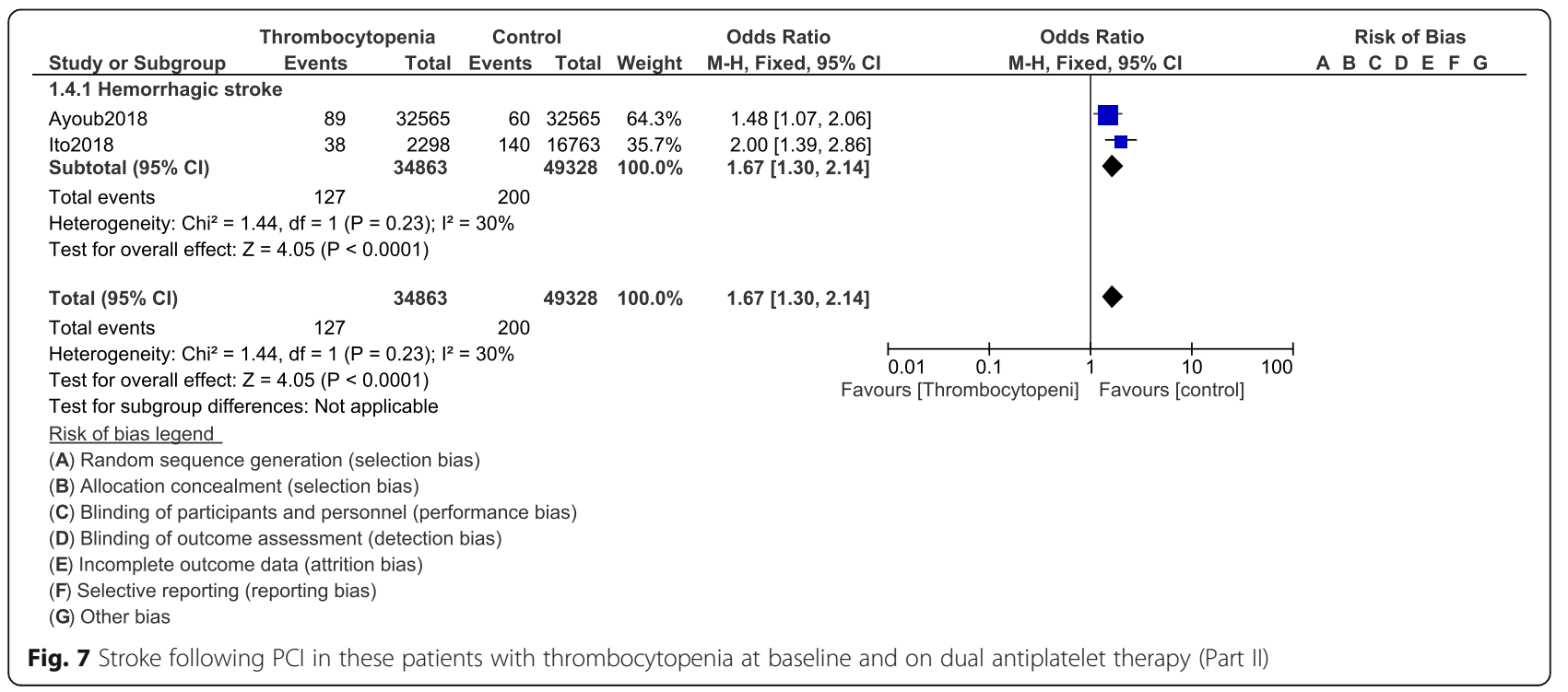




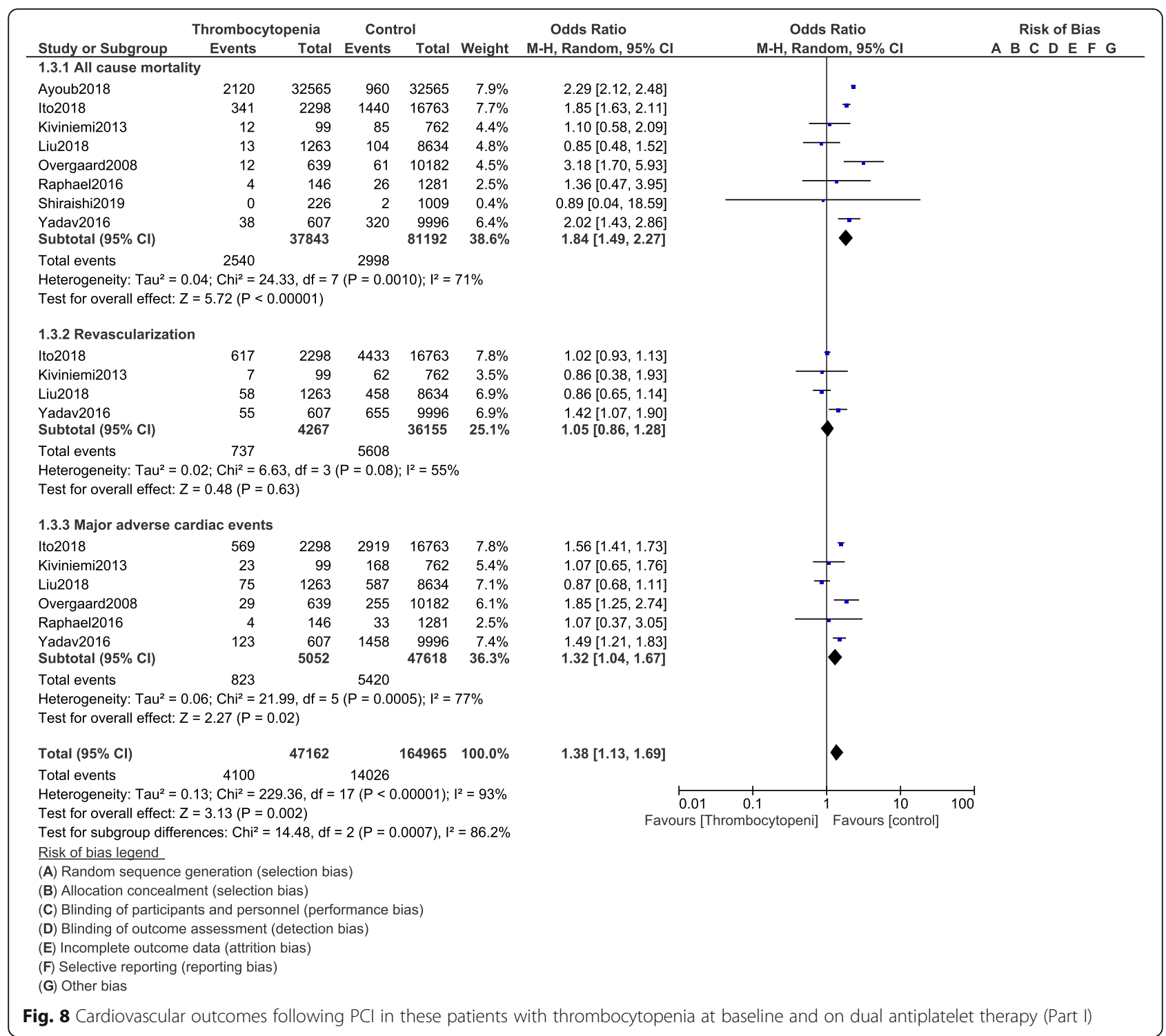

presentation. Our current analysis already involved participants with thrombocytopenia, and therefore, logically, longer duration of DAPT use might not be tolerable in similar patients following PCI. Another study showed short term DAPT use to be equally effective and safer compared to long term DAPT use following stents implantation with drug eluting stents [30].

This analysis was based on patients with thrombocytopenia at baseline, and who underwent PCI and who were followed up on DAPT. It should be noted that in this study, thrombocytopenia was already confirmed prior to $\mathrm{PCI}$ and not following the use of certain types of anticoagulants [31, 32].

\section{Limitations}

This present meta-analysis based on PCI in patients with thrombocytopenia at baseline has certain limitations. First of all, most of the data were obtained from observational studies which might result in the introduction of bias and other confounding factors that might have affected the results. Secondly, the anticoagulants and antiplatelet agents which were used during the invasive procedure were not clearly stated. This is quite an important information which was not fully reported in the original papers and might be another vital limitation of this analysis. In addition, in two studies, the anti-platelet regimens after the procedure were not mentioned. Hence, we are not sure if DAPT was used or these patients were treated on mono-therapy following PCI. This could be another limitation of this study. Moreover, in one study, the participants were treated with aspirin and warfarin as the anticoagulants after PCI whereas all the other studies reported aspirin and P2Y12 inhibitors (mainly clopidogrel). Also, the definition of thrombocytopenia varied in some 


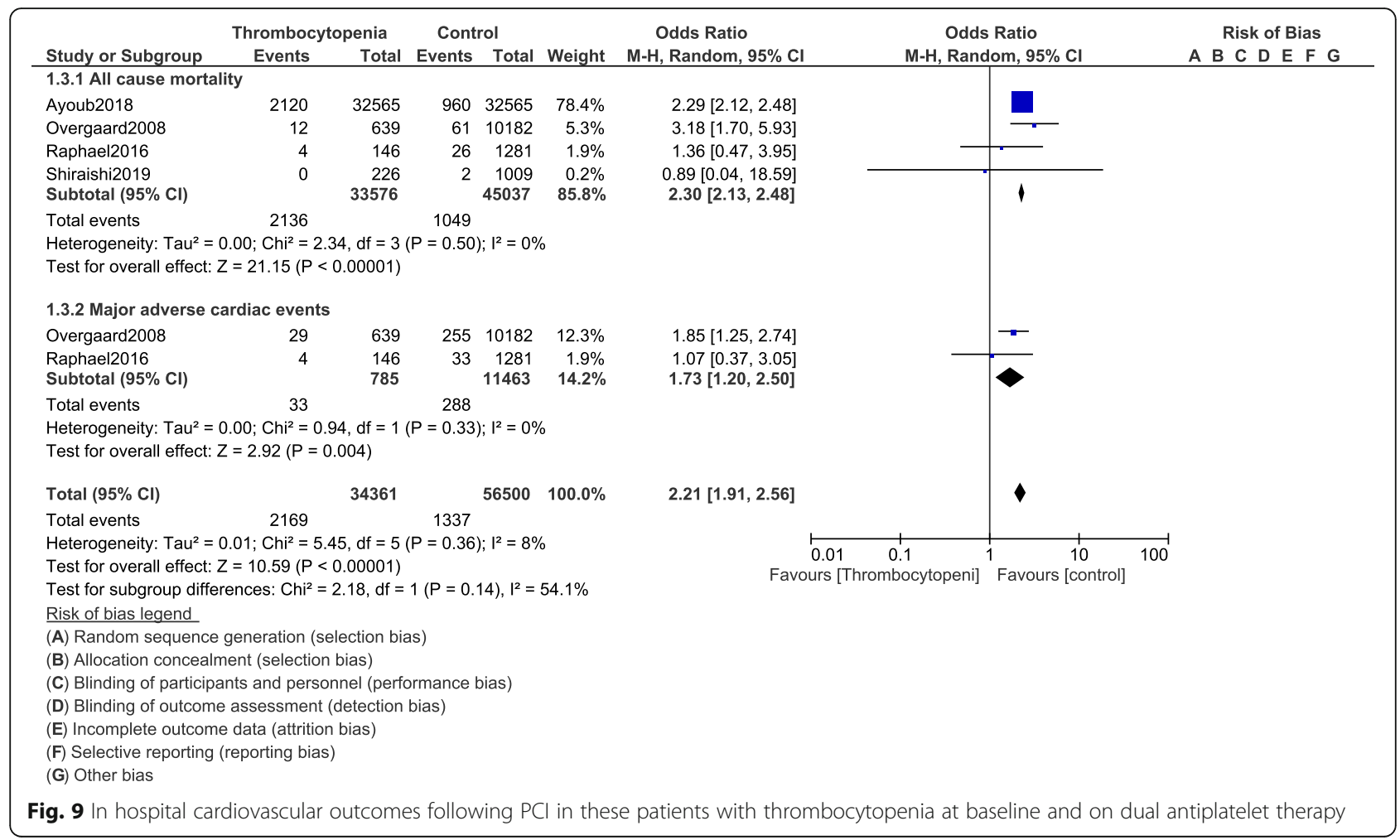

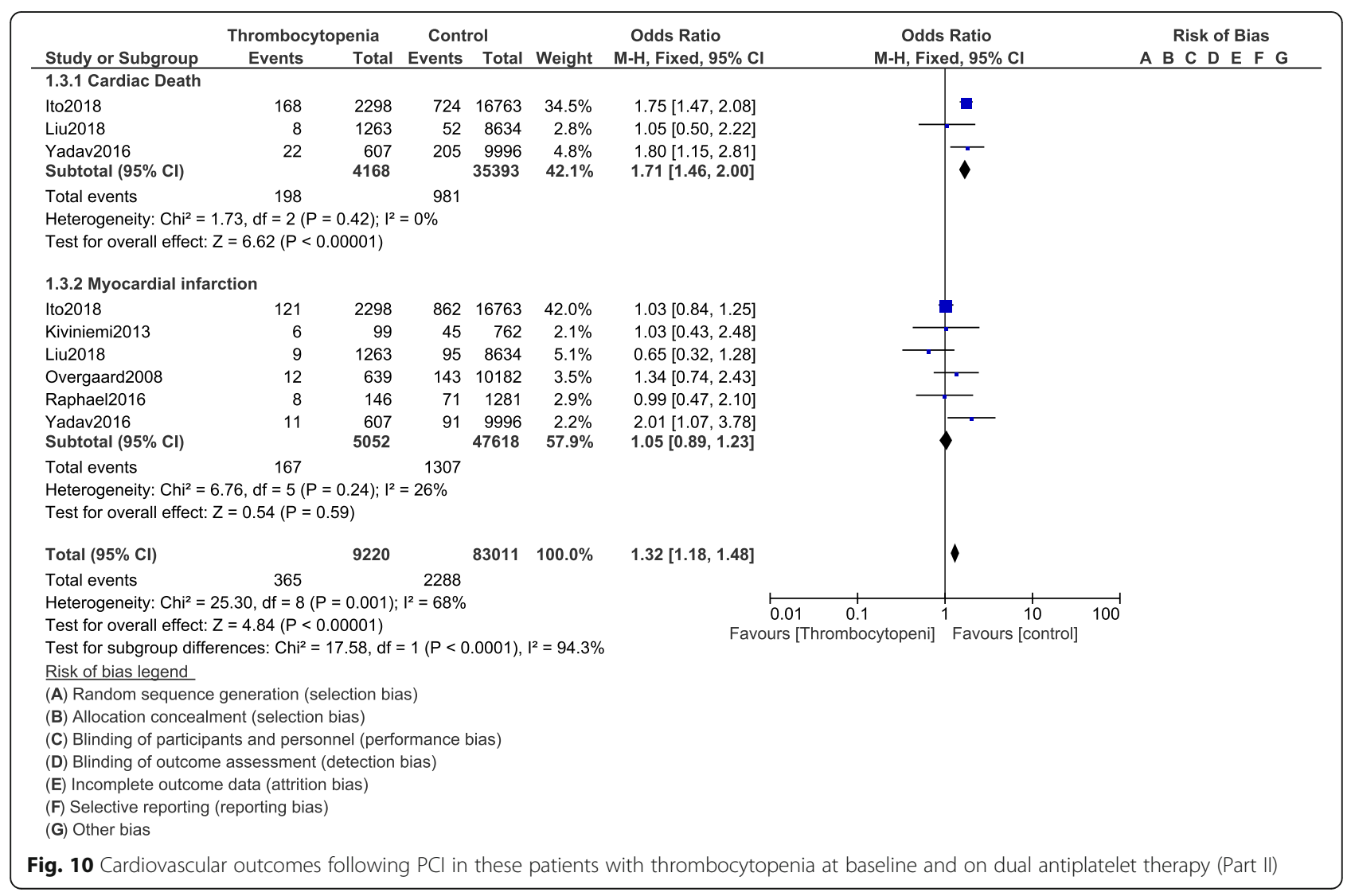




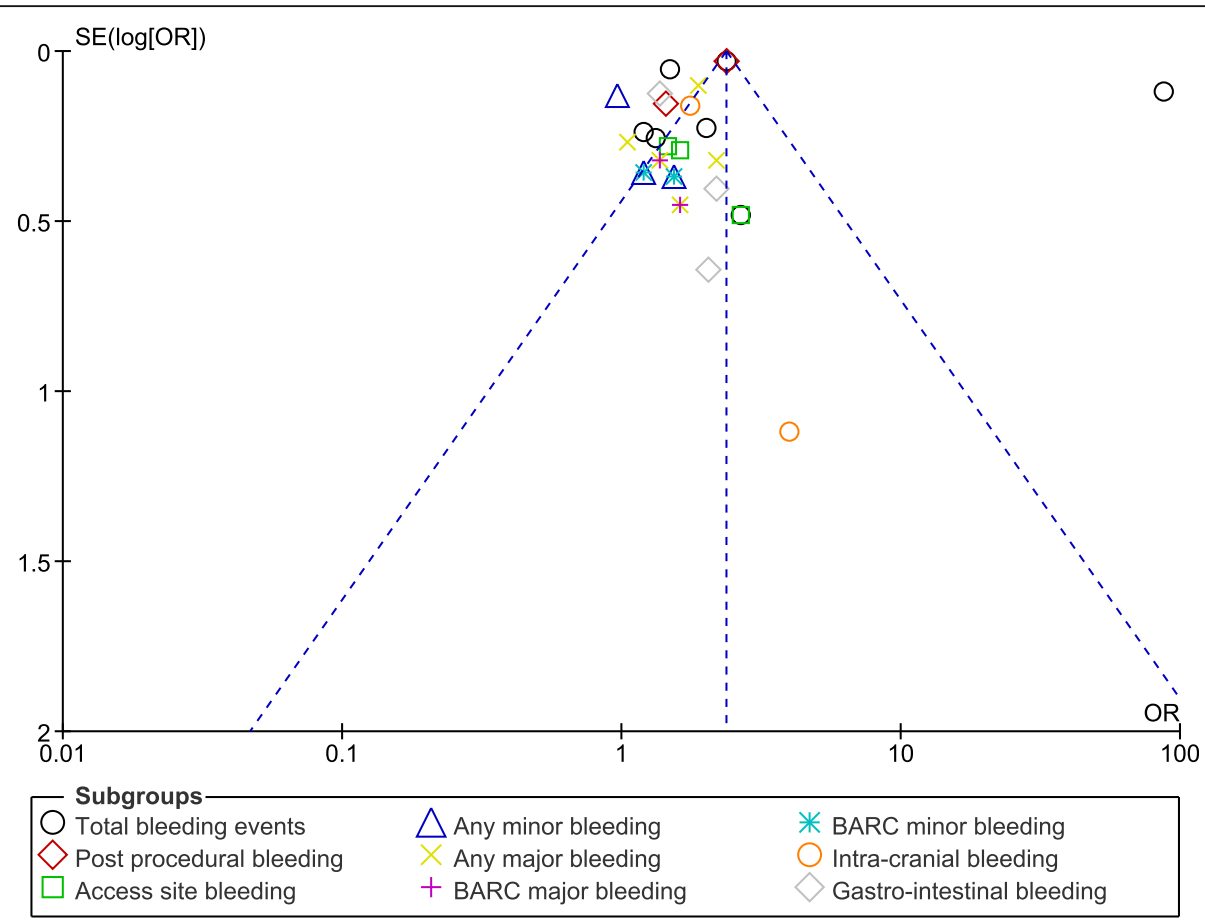

Fig. 11 Funnel plot representing any evidence of publication bias (A)

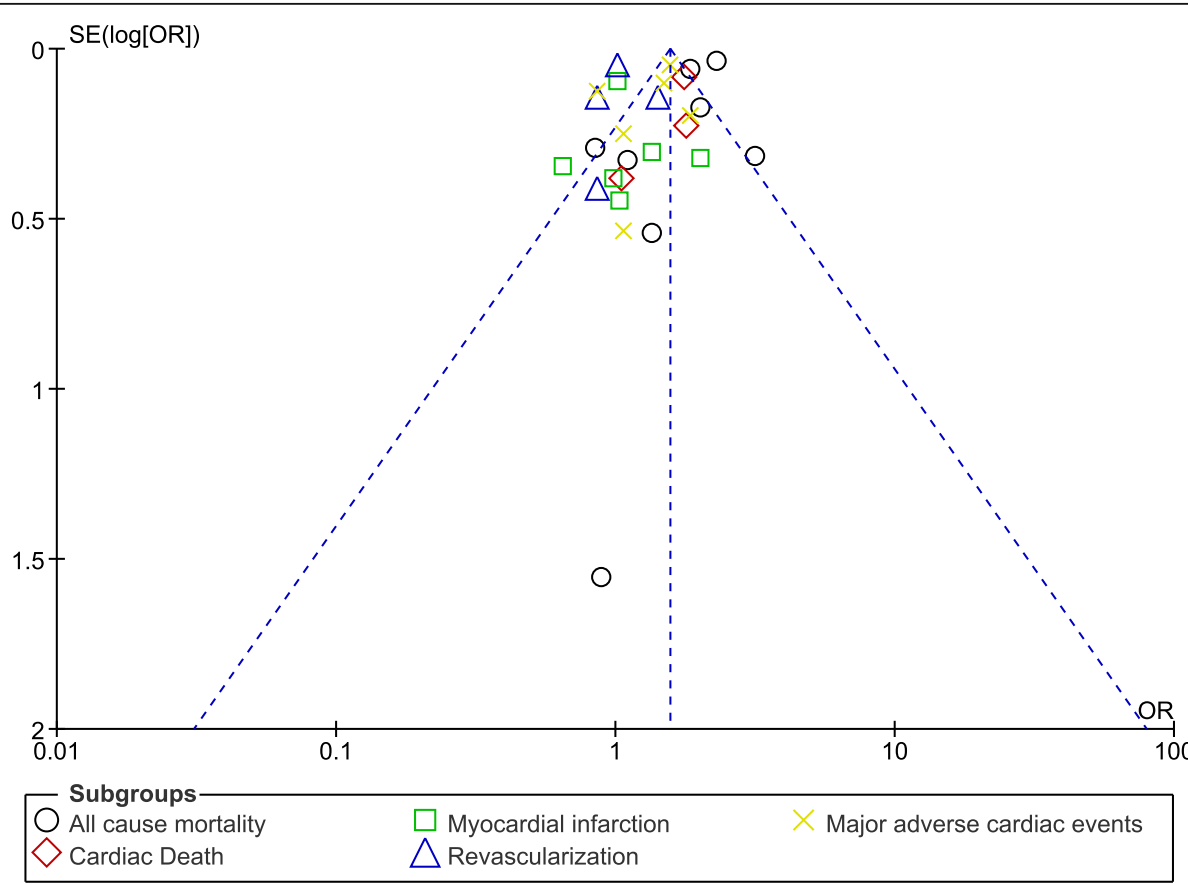

Fig. 12 Funnel plot representing any evidence of publication bias (B) 
studies and this analysis included a mixture of mild and moderate thrombocytopenic patients. However, the range of platelet count which was stated in most of the studies was almost similar. Furthermore, access site bleeding which was one of the outcomes, was strictly dependent on the procedural access sites which were involved (radial or femoral). Normally a radial access is associated with lower bleeding risk in comparison to the femoral access. However, several original studies did not mention about which access sites were involved and this might be another limitation of this analysis. In addition, it should be noted that the causes of thrombocytopenia are major determinants of prognosis following PCI in these patients. However, in this study, we were unable to analyze prognosis on the basis of mechanism causing platelet deficit and for this reason the results on mortality might not be generalized and would require more dedicated studies. At last, the duration of DAPT use was also not reported in most of the original studies and this might also contribute to a major limitation of this study.

\section{Conclusions}

According to the results of this analysis, DAPT might have to be cautiously be used following PCI in a population of patients with thrombocytopenia at baseline due to the significantly higher bleeding rate including gastrointestinal, intra-cranial bleeding and hemorrhagic stroke. Hence, special care might have to be taken when considering anti-platelet agents following PCI in these high risk patients. However, considering the present limitations of this analysis, this hypothesis will have to be confirmed in future trials.

\section{Abbreviations}

PCI: Percutaneous coronary intervention; MACEs: Major adverse cardiac events; ST: Stent thrombosis; OR: Odd ratios; DAPT: Dual anti-platelet therapy

\section{Acknowledgements}

Not applicable.

\section{Authors' contributions}

The authors $M L, Z Y, J Z, W C$ and $L L$ were responsible for the conception and design, acquisition of data, analysis and interpretation of data, drafting the initial manuscript and revising it critically for important intellectual content. Author ML wrote this manuscript. All the authors agreed to and approved the manuscript as it has been written.

\section{Authors' information}

Dr. Manyun Long is the first author of this manuscript.

\section{Funding}

This work was supported by Medical Healthcare Technology Development and Promotion Application Foundation of Guangxi (No. S2018054 and No. S2017036) and the Project for Innovation Research Team in Guangxi Natural Science Foundation (2018GXNSFGA281006). There was no external source of funding for this research.

\section{Availability of data and materials}

All data and materials used in this research are freely available in electronic databases (MEDLINE, EMBASE, Cochrane database, Google scholar). References have been provided.
Ethics approval and consent to participate

Ethical approval was not applicable for this systematic review and metaanalysis.

\section{Consent for publication}

Not applicable.

\section{Competing interests}

The authors declare that they have no competing interests.

Received: 3 August 2019 Accepted: 14 April 2020

Published online: 25 April 2020

\section{References}

1. Kereiakes DJ, Berkowitz SD, Lincoff AM, Tcheng JE, Wolski K, Achenbach R, Melsheimer R, Anderson K, Califf RM, Topol EJ. Clinical correlates and course of thrombocytopenia during percutaneous coronary intervention in the era of abciximab platelet glycoprotein Ilb/llla blockade. Am Heart J. 2000;140(1): 74-80.

2. Dauerman HL. Anticoagulation strategies for primary percutaneous coronary intervention: current controversies and recommendations. Circ Cardiovasc Interv. 2015;8(5)

3. Deharo P, Cuisset T. Optimal duration of dual antiplatelet therapy post percutaneous coronary intervention in acute coronary syndrome. Trends Cardiovasc Med. 2020;30(4):198-202.

4. Hakim DA, Dangas GD, Caixeta A, Nikolsky E, Lansky AJ, Moses JW, Claessen B, Sanidas E, White HD, Ohman EM, Manoukian SV, Fahy M, Mehran R, Stone GW. Impact of baseline thrombocytopenia on the early and late outcomes after ST-elevation myocardial infarction treated with primary angioplasty: analysis from the harmonizing outcomes with revascularization and stents in AcuteMyocardial infarction (HORIZONS-AMI) trial. Am Heart J. 2011;161(2): 391-6.

5. Doesch C, Krämer B, Geisler T, May AE, Kroeber SM, Kandolf R, Gawaz M. Challenges in the treatment of patients with essential thrombocythemia and acute coronary syndrome. J Thromb Thrombolysis. 2008;25(2):193-7.

6. McCarthy CP, Steg G, Bhatt DL. The management of antiplatelet therapy in acute coronary syndrome patients with thrombocytopenia: a clinical conundrum. Eur Heart J. 2017;38(47):3488-92.

7. Warkentin TE, Crowther MA. Adverse prognostic significance of thrombocytopenia in acute coronary syndrome: can anything be done about it? Circulation. 2009:119(18):2420-2.

8. Ayoub K, Marji M, Ogunbayo G, Masri A, Abdel-Latif A, Ziada K, Vallurupalli S. Impact of chronic thrombocytopenia on in-hospital outcomes after PercutaneousCoronary intervention. JACC Cardiovasc Interv. 2018;11(18): $1862-8$

9. Ito S, Watanabe H, Morimoto T, Yoshikawa Y, et al. Impact of baseline thrombocytopenia on bleeding and mortality after percutaneous coronary intervention. Am J Cardiol. 2018:121(11):1304-14.

10. Kiviniemi T, Karjalainen P, Rubboli A, Schlitt A, Tuomainen P, Niemelä M, Laine M, Biancari F, Lip GY, Airaksinen KE. Thrombocytopenia in patients with atrial fibrillation on oral anticoagulation undergoing percutaneous coronary intervention. Am J Cardiol. 2013;112(4):493-8.

11. Liu S, Song C, Zhao Y, Guan C, Zhu C, Feng L, Xu B, Dou K. Impact of baseline thrombocytopenia on the long-term outcome of patients undergoing electivepercutaneous coronary intervention: an analysis of 9,897 consecutive patients. Catheter Cardiovasc Interv. 2019;93(S1):764-71.

12. Overgaard CB, Ivanov J, Seidelin PH, Todorov M, Mackie K, Dzavík V. Thrombocytopenia at baseline is a predictor of in hospital mortality in patients undergoing percutaneous coronary intervention. Am Heart J. 2008; 156(1):120-4.

13. Raphael CE, Spoon DB, Bell MR, et al. Effect of Preprocedural thrombocytopenia on prognosis after percutaneous coronary intervention. Mayo Clin Proc. 2016;91(8):1035-44.

14. Shiraishi J, Koshi N, Matsubara Y, et al. Effects of baseline thrombocytopenia on in-hospital outcomes in patients undergoing ElectivePercutaneous coronary intervention. Intern Med. 2019. https://doi.org/10.2169/ internalmedicine.2063-18.

15. Yadav M, Généreux P, Giustino G, et al. Effect of baseline thrombocytopenia on ischemic outcomes in patients with acute CoronarySyndromes who undergo percutaneous coronary intervention. Can J Cardiol. 2016;32(2):226-33. 
16. Kikkert WJ, van Geloven N, van der Laan MH, Vis MM, Baan J Jr, Koch KT, Peters RJ, de Winter RJ, Piek JJ, Tijssen JG, Henriques JP. The prognostic value of bleeding academic research consortium (BARC)-defined bleeding complications in ST-segment elevation myocardial infarction: a comparison with the TIMI (Thrombolysis In Myocardial Infarction), GUSTO (Global Utilization of Streptokinase and Tissue Plasminogen Activator for Occluded Coronary Arteries), and ISTH (International Society on Thrombosis and Haemostasis) bleeding classifications. J Am Coll Cardiol. 2014;63(18):1866-75.

17. Mauri L, Hsieh WH, Massaro JM, Ho KK, D'Agostino R, Cutlip DE. Stent thrombosis in randomized clinical trials of drug-eluting stents. N Engl J Med. 2007;356(10):1020-9.

18. Stang A. Critical evaluation of the Newcastle-Ottawa scale for the assessment of the quality of nonrandomized studies in meta-analyses. Eur J Epidemiol. 2010;25(9):603-5.

19. Higgins JP, Altman DG, Gøtzsche PC, Jüni P, Moher D, Oxman AD, Savovic J, Schulz KF, Weeks L, Sterne JA, Cochrane Bias Methods Group; CochraneStatistical Methods Group. The Cochrane Collaboration's tool for assessing risk of bias in randomised trials. BMJ. 2011;343:d5928.

20. Liberati A, Altman DG, Tetzlaff J, Mulrow C, Gøtzsche PC, loannidis JP, Clarke M, Devereaux PJ, Kleijnen J, Moher D. The PRISMA statement for reporting systematic reviews and meta-analyses of studies that evaluate healthcare interventions: explanation and elaboration. BMJ. 2009;339:b2700.

21. Berkowitz SD, Sane DC, Sigmon KN, Shavender JH, Harrington RA, Tcheng JE, Topol EJ, Califf RM. Occurrence and clinical significance of thrombocytopenia in a population undergoing high-riskpercutaneous coronary revascularization. Evaluation of C7E3 for the prevention of ischemic complications (EPIC) study group. J Am Coll Cardiol. 1998;32(2):311-9.

22. Sušilović Grabovac Z, Baković D, Lozo M, Pintarić I, Dujić Ž. Early changes in platelet size and number in patients with acute coronary syndrome. Int J Angiol. 2017;26(4):249-52.

23. Fernández-Fernández FJ, Ameneiros-Lago E, Tuñas-Gesto C, Gómez-Buela I. Antiplatelet therapy in a patient with coronary artery disease and Myelodysplastic Syndromewith thrombocytopenia. Acta Med (Hradec Kralove). 2017;60(2):82-4

24. Campo G, Marchesini J, Fileti L, Tebaldi M, Ferrari R. Medical and interventional management of patients with severe thrombocytopenia undergoing percutaneous coronary intervention. J Thromb Haemost. 2012; 10(1):153-6

25. Staib P, Forsch S, Niedeggen A, Janssens U. Percutaneous coronary intervention in a patient with acute myeloid leukemia. Dtsch Med Wochenschr. 2012;137(21):1092-5.

26. Wang J, Chen R, Lin X, Wang Y, Wang JH, Wu Y. New perspectives on treatment strategies for patient with acute myeloid leukemia and complex karyotype abnormalities after percutaneous coronary intervention: a case report. Medicine (Baltimore). 2019;98(30):e16586.

27. Krill T, Brown G, Weideman RA, Cipher DJ, Spechler SJ, Brilakis E, Feagins LA. Patients with cirrhosis who have coronary artery disease treated with cardiac stents have high rates of gastrointestinal bleeding, but no increased mortality. Aliment Pharmacol Ther. 2017;46(2):183-92.

28. Bianco M, D'ascenzo F, Raposeiras Roubin S, et al. Comparative external validation of the PRECISE-DAPT and PARIS risk scores in 4424 acute coronary syndrome patients treated with prasugrel or ticagrelor. Int J Cardiol. 2020;301:200-6.

29. Palmerini T, Della Riva D, Benedetto $U$, et al. Three, six, or twelve months of dual antiplatelet therapy after DES implantation in patients with or without acute coronary syndromes: an individual patient data pairwise and network meta-analysis of six randomized trials and 11473 patients. Eur Heart J. 2017; 38(14):1034-43.

30. Sawaya FJ, Morice MC, Spaziano M, et al. Short-versus long-term dual antiplatelet therapy after drug-eluting stent implantation in women versus men: a sex-specific patient-level pooled-analysis of six randomized trials. Catheter Cardiovasc Interv. 2017;89(2):178-89.

31. Golden T, Ghazala S, Wadeea R, Junna S. Abciximab-induced acute profound thrombocytopenia postpercutaneous coronary intervention. BMJ Case Rep. 2017;14:2017.

32. Wessler JD, Giugliano RP. Risk of thrombocytopenia with glycoprotein IIb/ Illa inhibitors across drugs and patient populations: a meta-analysis of 29 large placebo-controlled randomized trials. Eur Heart J Cardiovasc Pharmacother. 2015;1(2):97-106.

\section{Publisher's Note}

Springer Nature remains neutral with regard to jurisdictional claims in published maps and institutional affiliations.

\section{Ready to submit your research? Choose BMC and benefit from:}

- fast, convenient online submission

- thorough peer review by experienced researchers in your field

- rapid publication on acceptance

- support for research data, including large and complex data types

- gold Open Access which fosters wider collaboration and increased citations

- maximum visibility for your research: over $100 \mathrm{M}$ website views per year

At BMC, research is always in progress.

Learn more biomedcentral.com/submissions 